\title{
An Appraisal of the Performance of National Poverty Eradication Programme (NAPEP) On Poverty Reduction in Bauchi State
}

\author{
${ }^{1}$ Bashir Muhammad Abubakar, ${ }^{2}$ Hussaini Adamu Hussaini \\ ${ }^{1 \& 2}$ Department of General Studies, Federal Polytechnic, P.M.B. 0231, Bauchi State, Nigeria;
}

\begin{abstract}
This paper examines the activities of National Poverty Eradication Programme (NAPEP) on poverty reduction in Bauchi State. The paper assesses the performance of these activities vis-à-vis their impact on the socio-economic lives of the beneficiaries in Bauchi Local Government Area of Bauchi State. Data for the study was collected through questionnaire and In-depth Interviews. The information required was gathered from 210 respondents consisting of 200 beneficiaries and 10 officials of NAPEP, Bauchi state office. The respondents were selected through the use of systematic and availability sampling techniques. Data collected in the study were presented and analysed using simple frequency, percentages and cross tabulation. Chi-square was used to gauge the performance of NAPEP on poverty reduction in Bauchi State. The study revealed that the programme has impacted positively on the beneficiaries, especially in the areas of job creation, improvement in income, improvement in raising the respondents' level of education, improvement in social status, etc. It was however, observed that in spite of this performance achievement, the programme needs to do more considering the people so far reached and the amount of money invested into the programme since inception. It was observed that problems like lack of proper selection of beneficiaries, lack of commitment and dedication on the part of the beneficiaries, lack of proper monitoring and evaluation, inability or failure of the authorities concerned to properly set up some of the beneficiaries, hinder smooth execution of the programme in Bauchi State. The study concluded by recommending among other things the use of guarantors in identifying and selecting the beneficiaries with a view to ensuring that materials given to a beneficiary on placement are not disposed off unnecessarily.
\end{abstract}

Key words: Poverty, Poverty Reduction, National Poverty Eradication Programme and Performance

\section{General Background}

Poverty is a serious social problem confronting Nigeria and other nations of the world. The rising profile of poverty in Nigeria is assuming a worrisome dimension as empirical studies have shown. In 1999, after the return of democratic rule, estimates put the poverty rate in the country at close to 70 percent; perhaps, $40 \%$ of these people are the 'core poor', so impoverished that they cannot meet their basic food need (Ogwumike, 2003). In 2004, virtually three years after the full implementation of NAPEP in the country, poverty incidence in the country was estimated at 54.68 percent at national level or 68.7 million people were classified poor based on the Nigerian Living Standard Survey (2004). The Harmonised Nigeria Living Standard Survey (2010) recently released by the National Bureau of Statistics puts the Nigeria's poverty incidence at 69 percent or 112.47 million people are classified as people living in poverty. The Nigeria Bureau of Statistics puts the poverty forecast of Nigeria for 2011 at 71.5, 61.9 and 62.8 percent being relative, absolute and dollar per day measure of poverty in Nigeria respectively (National Bureau of Statistics, 2004; National Bureau of Statistics, 2010).

Historically, poverty has been a source of concern in societies and this explains why governments at various levels are making efforts towards reducing it (Obadan, 1996). In Nigeria, there have been several attempts by government and non-governmental organisations to reduce the high prevalence of poverty in the country. The measures so far implemented have focused more on economic growth, basic needs, targets population and rural development approaches. According to (Garba, 2006; Ogwumike, 2003), these poverty reduction efforts can be delineated in to three broad phases or eras: the pre-SAP Era, the SAP Era and the PostSAP or Democratic Era. Although previous government's efforts aimed at alleviating poverty in the country did not come under the "poverty reduction" nomenclature or slogan, several institutions have emerged and have been concerned with poverty reduction in various ways.

Despite the enormous human and material resources used by successive governments to reduce poverty with the support of richer nations, donor agencies, Community Based Organizations, development partners, and Non-Governmental Organizations, the programmes, which were put in place, have failed to produce the desired positive impact on the poor. Some of the factors associated with the failure of the programmes include: policy inconsistency and poor governance, ineffective targeting of the poor (leading to leakage of benefits to unintended beneficiaries), overlapping of functions, lack of transparency, lack of involvement of social partners and other stake holders in planning, implementation and evaluation, poor human capital development and 
inadequate funding, failure to identify the poor and the nature of their poverty, corruption, to mention but a few (Ajakaiye, 2002).These unsatisfactory results therefore, call for a re-examination and re-structuring of policies and practices of poverty reduction in Nigeria.

By early 2001, a comprehensive National Poverty Eradication Programme (NAPEP) was fully drawn up by the Federal Government with the prime aim of eradicating core (extreme) poverty in the country by the year 2010, generally in line with the United Nations Millennium Development Goals (MDGs) of halving the proportion of people living in poverty by the year 2015. To achieve its objectives, NAPEP designed four schemes namely;

(1) Youth Empowerment Schemes (YES), which aims at providing opportunities through programmes in skills acquisition, employment and wealth generation.

(2) Rural Infrastructure Development Scheme (RIDS), which aims at ensuring the provision and development of critical infrastructure needs, including transport, energy, water and communication particularly in rural areas.

(3) Social Welfare Services Scheme (SOWESS), which aims at ensuring the provision of adequate basic social welfare services including quality primary and special education, farmers empowerment, primary health care, etc; and

(4) Natural Resources Development and Conservation Scheme (NRDCS), that aims at ensuring higher participatory and sustainable development of agricultural, mineral and water resources while caring for the environment (Aliyu, 2001).

However, several other schemes were developed by NAPEP in its subsequent attempts to contain the increasing wave of poverty in the country.

\section{Statement of the Problem}

In Nigeria, there have been several attempts by successive governments in the country to curve the increasing scourge of poverty, what is disturbing however, is the extent to which these programmes and practices of poverty reduction have impacted on the poor. Studies on the subject of poverty and agencies concerned with its reduction in Nigeria indicate that considerable gap exists between the target objective (reducing poverty) and achievement (Aliyu, 2001; Ajakaiye, 2002).

The description of Nigeria as a paradox by the World Bank (1999) has continued to prevail by events and official statistics in the country. The paradox is that the poverty level in the country contradicts the country's immense wealth. Among other things, the country is highly endowed with human, agricultural, petroleum and large untapped solid minerals resources. However, rather than record remarkable progress in national socio-economic development, Nigeria retrogressed to become the 25 poorest country at the thresh hold of the twenty first century where as she was among the richest 50 in the early 1970s (World Bank, 1999).

In the light of the government's concern for poverty reduction, numerous policies and programmes have been designed at one time or another, if not to meet the special needs of the poor, at least to reach them. By the end of 1998, there were sixteen poverty alleviation institutions in the country (Obadan, 1996). The seventeenth came into effect in 2001 after return of democratic rule in 1999.

At the return to democratic government in May, 1999 the Government embarked on Poverty Alleviation Programme (PAP), which aimed at job creation. In 2001, the government then established the National Poverty Eradication Programme (NAPEP). An important objective of NAPEP is to help "eradicate" extreme poverty by the year 2010, in line with United Nation's Millennium Development Goals (MDGs) of halving the proportion of people living in poverty by the year 2015 .

Barely two years to the expiration of MGDs, the main trust of this paper is to assess the extent to which NAPEP's activities and programmes impacted on the beneficiaries especially in the areas of job creation, improvement in living condition, improvement in economic standing and improvement in the educational attainment of the beneficiaries.

The following hypotheses were generated and tested

\section{Research Hypotheses}

1. Programmes and activities of NAPEP have impacted positively on the socio-economic lives of the beneficiaries

2. Programmes and activities of NAPEP have not impacted positively on the socio-economic lives of the beneficiaries

3. NAPEP's approach to poverty alleviation has been positively appraised by the beneficiaries

4. NAPEP's approach to poverty alleviation has not been positively appraised by the beneficiaries 


\section{Research Design}

This empirical study is a descriptive research which entails recording, analyzing and interpreting conditions that exist. It involves some kind of comparison and attempts to discuss the relationships between existing, non manipulated variables upon which generalization was made. This research process is mostly used in education and social sciences generally (Williams, 2003).

\subsection{Population and Sample}

The population of the study comprises of beneficiaries and officials of National Poverty Eradication Programme in Bauchi Local Government Area of Bauchi State. A sample of two hundred and ten (210) respondents was selected for this study. To facilitate easy access to information needed the respondents were broken down in to two categories: The beneficiaries of the programme and the officials of the programme. In this regard, 200 beneficiaries were drawn from a total list of 1,000 beneficiaries from Bauchi Local government while 10 officials of NAPEP Bauchi State office were selected from a total list of 32 staff. The 200 beneficiaries comprised of 159 male and 41 female but, all the officials of NAPEP in Bauchi State office are male. Thus, all the 10 officials interviewed are males.

Because the sampling frame of the beneficiaries and that of the officials were easily obtained from NAPEP, systematic and availability sampling techniques were used in selecting the 210 respondents respectively. In this regard, the 200 beneficiaries were drawn from a total list of 1,000 beneficiaries using systematic sampling method based on a sampling fraction of $1 / 5$. As for the officials of NAPEP, availability sampling method was used in selecting the ten officials interviewed.

\subsection{Instrument}

Data obtained from the field were collected through the use of questionnaire and interview. The questionnaire which was constructed in English Language comprised of both open and closed-ended questions. The body of the questionnaires consists of two parts: Part one gives information on the demographic data of the respondents while the second part gives information on the types of benefits derived from the scheme by the beneficiaries and how the benefits improved their socio-economic status. The questionnaire, which was interviewer administered, was administered on the respondents with the support of four research assistants. The interviews were conducted on the NAPEP officials of Bauchi state office with the help of interview guide. The researcher also studied and reviewed relevant materials and documents from NAPEP head office such as books, seminar Papers, Magazines, pamphlets and blue prints.

\subsection{Methods of Data Analysis}

Descriptive statistics of frequency count, percentages, cross tabulation; and inferential statistics of Chisquare were used as appropriate to the research hypotheses raised in the study. The soft ware SPSS (V. 16.0) was used to process the research data.

\subsection{Hypotheses Test I}

\section{Results and Discussion}

1. Programmes and activities of NAPEP have impacted positively on the socio-economic lives of the beneficiaries

2. Programmes and activities of NAPEP have not impacted positively on the socio-economic lives of the beneficiaries

\subsubsection{Impact of NAPEP's activities on the beneficiaries}

\section{Solution}

Using the formula $\chi^{2}=\frac{\sum(o-\ell)^{2}}{\ell}$

Where $\chi^{2}=$ Chi square (calculated value)

$\mathrm{O}=$ Observed frequencies

$\ell=$ Expected frequencies

\begin{tabular}{|l|c|c|c|c|c|}
\hline Responses & Freq.( $\boldsymbol{O})$ & $\ell$ & $0-\ell$ & $(0-\ell)^{2}$ & $(0-\ell)^{2} / \ell$ \\
\hline Yes & 191 & 100 & 91 & 8281 & 82.81 \\
\hline No & 9 & 100 & -91 & 8281 & 82.81 \\
\hline Total & & & & & 165.62 \\
\hline
\end{tabular}

The degree of freedom $d f=\mathrm{k}-1=2-1=1 ; \quad X^{2}{ }_{0.05,1}=3.841$ 


\section{Decision Rule:}

The null hypothesis is rejected, since the calculated value of chi-square (165.62) is greater than the table value of (3.841). We conclude that the respondents agreed that NAPEP's programmes and activities have impacted positively on their socio-economic lives at 0.05 levels.

\subsubsection{Specific impacts of NAPEP's activities to the beneficiaries}

\section{Solution}

Using the formula $\chi^{2}=\frac{\sum(o-\ell)^{2}}{\ell}$

Where $\chi^{2}=$ Chi square (calculated value)

$\mathrm{O}=$ Observed frequencies

$\ell=$ Expected frequencies

\begin{tabular}{|l|c|c|c|c|c|}
\hline Responses & Freq. $(\boldsymbol{O})$ & $\ell$ & $0-\ell$ & $(0-\ell)^{2}$ & $(0-\ell)^{2} / \ell$ \\
\hline Improve my income & 47 & 38.2 & 8.8 & 77.44 & 2.03 \\
\hline Create job opportunity for me & 65 & 38.2 & 26.8 & 718.24 & 18.80 \\
\hline Raise my social status & 16 & 38.2 & -22.2 & 492.84 & 12.90 \\
\hline Improve my education & 5 & 38.2 & -33.2 & 1102.24 & 28.85 \\
\hline All of the above & 58 & 38.2 & 19.8 & 392.04 & 10.26 \\
\hline Total & & & & & 72.84 \\
\hline
\end{tabular}

The degree of freedom $d f=\mathrm{k}-1=5-1=4 ; \quad X^{2}{ }_{0.05},{ }_{4}=9.488$

\section{Decision Rule:}

The null hypothesis is rejected, since the calculated value of chi-square (72.84) is greater than the table value of (9.488). We conclude that NAPEP's programmes and activities have impacted positively on the socio-economic lives of the beneficiaries at 0.05 levels.

\subsection{Hypotheses Test II}

1. NAPEP's approach to poverty alleviation has been positively appraised by the beneficiaries

2. NAPEP's approach to poverty alleviation has not been positively appraised by the beneficiaries

\subsubsection{Assessment of NAPEP by the beneficiaries}

\section{Solution}

Using the formula $\chi^{2}=\frac{\sum(o-\ell)^{2}}{\ell}$

Where $\chi^{2}=$ Chi square (calculated value)

$\mathrm{O}=$ Observed frequencies

$\ell=$ Expected frequencies

\begin{tabular}{|l|c|c|c|c|c|}
\hline Responses & Freq. $(\boldsymbol{O})$ & $\ell$ & $0-\ell$ & $(0-\ell)^{2}$ & $(0-\ell)^{2} / \ell$ \\
\hline No response & 1 & 33.3 & -32.3 & 542.89 & 16.30 \\
\hline Good & 93 & 33.3 & 59.7 & 44.89 & 1.35 \\
\hline Very good & 60 & 33.3 & 26.7 & 278.89 & 8.36 \\
\hline Excellent & 27 & 33.3 & -6.3 & 39.69 & 1.19 \\
\hline Poor & 15 & 33.3 & 18.3 & 334.89 & 10.06 \\
\hline Very poor & 4 & 33.3 & -29.3 & 858.49 & 25.78 \\
\hline Total & & & & 63.04 \\
\hline
\end{tabular}

The degree of freedom $d f=\mathrm{k}-1=6-1=5 ; \quad X^{2}{ }_{0.05,5}=11.070$

\section{Decision Rule:}

The null hypothesis is rejected, since the calculated value of chi-square (63.04) is greater than the table value of (11.070). We conclude that the beneficiaries of NAPEP's programme and activities have positively assessed the performance of NAPEP toward poverty reduction in Bauchi Local Government at 0.05 levels. 


\section{Conclusion and policy implication}

The study set out to empirically examine the performance of National Poverty Eradication Programme (NAPEP) towards poverty eradication in Bauchi Local Government Area of Bauchi State, with a view to determining whether the programme has made the desired impact on the beneficiaries in Bauchi Local Government Area. The major findings of the study are that, NAPEP's programmes and activities have impacted positively on the socio-economic lives of the beneficiaries, and that, the performance of NAPEP towards poverty alleviation has been commended by the beneficiaries. This implies that the programme, in spite of narrow coverage and outreach, has the potential of making impact on poverty reduction in Nigeria if effectively and transparently utilised.

Finally, given the limited resources available to the organisation and the limitless number of legible beneficiaries in the country, there is the need to streamline poverty reduction apparatus of the government in order to consolidate gains so far recorded and avert waste of public resources and duplication of functions with regards to poverty alleviation effort.

\section{Bibliography}

[1] Ajakaiye, O. (2002). Appraising Poverty Reduction Strategies in Nigeria. Poverty Reduction Stategies in Nigeria. Kano: Mumbayya House.

[2] Aliyu, A. (2001). National Poverty Eradication Programme (NAPEP): Completion, Implementation, Coordination and Monitoring. Abuja: NAPEP.

[3] Garba, A. (2006). Alleviating Poverty in Nigeria. Annual Conference of Zumunta Association. Minneapolis, MN.

[4] National Bureau of Statistics. (2004). Poverty Profile in Nigeria: Nigeria Living Standard Survey. Abuja: National Bureau of Statistics.

[5] National Bureau of Statistics. (2010). Nigeria Poverty Profile: The Harmonised Nigeria Living Standard Survey. Abuja: National Bureau of Statistics.

[6] Obadan, M. I. (1996). Poverty in Nigeria: Characterestics, Alleviation Strategies and Programmes. NCEMA Analysis Series, Vol. 2, NO. 2.

[7] Ogwumike, F. O. (2003). An Appraisal of Poverty Reduction Strategies in Nigeria. Abuja: CBN Economics and Financial Reviews, Vol. 39, NO. 4.

[8] Williams, M. a. (2003). Introduction to the Philosophy of Social Research. London: University College London Press Limited.

[9] World Bank. (1999). Nigeria: Poverty in the midst of plenty. Washington DC: World Bank Group.

\section{APPENDIXES}

Table 1: Sex vs. Age Distribution of the Respondents

\begin{tabular}{|l|c|c|c|c|c|}
\hline \multirow{2}{*}{ Sex } & \multicolumn{3}{|c|}{ Age } & \multicolumn{2}{c|}{ Total } \\
\cline { 2 - 6 } & Below 18 Yrs & $18-37$ & $38-55$ & 26 Above \\
\hline Male & 28 & 106 & 22 & 3 & 2 \\
\hline Female & 5 & 30 & 4 & 59 & 41 \\
\hline Total & 33 & 136 & 26 & 200 \\
\hline
\end{tabular}

Table 1 above shows that majority of the respondents are within the age bracket of 18-37 years which is in line with the policy trust of the programme of youth empowerment. It is however, observed that female are underrepresented, a factor that may be attributed to socio-cultural as well as institutional rigidities in the area of the study.

Table 2: Marital Status vs. Educational Attainment of the Respondents

\begin{tabular}{|c|c|c|c|c|c|}
\hline \multirow{2}{*}{$\begin{array}{c}\text { Marital } \\
\text { Status }\end{array}$} & \multicolumn{4}{|c|}{ Educational Attainment } & \multirow[t]{2}{*}{ Total } \\
\hline & Primary Education & $\begin{array}{l}\text { Secondary } \\
\text { Education }\end{array}$ & $\begin{array}{c}\text { Tertiary } \\
\text { Education }\end{array}$ & $\begin{array}{l}\text { Adult \& Non formal } \\
\text { Education }\end{array}$ & \\
\hline Married & 18 & 41 & 24 & 2 & 85 \\
\hline Divorced & 4 & 3 & 2 & 0 & 9 \\
\hline Widow & 1 & 2 & 1 & 1 & 5 \\
\hline Total & 34 & 117 & 40 & 9 & 200 \\
\hline
\end{tabular}

Table 2 above indicates that majority of the respondents are holders of secondary education with a substantial number among them with tertiary education. The table also depicts that majority of the respondents are either single or married. This also is in line with the policy trust of the programme in the area of capacity acquisition and job creation.

Table 3: Income Level of the Respondents (before and after enrolment)

\begin{tabular}{|c|c|c|c|c|c|}
\hline $\begin{array}{c}\text { Level of Income } \\
\text { (Before } \\
\text { Enrollment) }\end{array}$ & $1000-4500$ & $4501-9500$ & $9501-14500$ & $14501-19500$ \\
\cline { 2 - 6 } & 3 & 2 & 0 & 0 \\
\hline NORESPONSE & 38 & 85 & 19 & 6 \\
\hline $1000-4500$ & & & 155 \\
\hline
\end{tabular}


An Appraisal Of The Performance Of National Poverty Eradication Programme (NAPEP) On

\begin{tabular}{|l|c|c|c|c|c|}
\hline $4501-9500$ & 5 & 11 & 8 & 3 \\
\hline $9501-14500$ & 1 & 3 & 0 & 4 \\
\hline $14501-19500$ & 0 & 0 & 2 & 9 \\
\hline Total & 47 & 101 & 29 & 3 \\
\hline
\end{tabular}

Table 3 above reveals an improvement in the earning of the beneficiaries after being enrolled in the programme. The table shows significant improvement in the income bracket of 4,501-9,500.

Table 4: Impact of the Programme on the socio-economic status of the Respondents

\begin{tabular}{|l|c|c|c|c|c|c|}
\hline \multirow{2}{*}{\begin{tabular}{c} 
Has the Scheme \\
you benefited \\
from helped to \\
improve your \\
\cline { 2 - 6 }
\end{tabular}} & $\begin{array}{c}\text { Improve my } \\
\text { Income } \\
\text { status? }\end{array}$ & $\begin{array}{c}\text { Create job Opportunity } \\
\text { for me }\end{array}$ & $\begin{array}{c}\text { Improve my } \\
\text { social status }\end{array}$ & $\begin{array}{c}\text { Improve my } \\
\text { Education }\end{array}$ & $\begin{array}{l}\text { All } \\
\text { the } \\
\text { above }\end{array}$ \\
\hline Yes & 47 & 65 & 16 & 5 & 58 & 191 \\
\hline Total & 47 & 65 & 16 & 5 & 58 & 191 \\
\hline
\end{tabular}

Table 4 above portrays the respondents' responses on how the programme impacted on their socio-economic lives. 191 of the respondents revealed that the programme has positively impacted on their lives especially in the areas of job creation, improvement in earnings and raising their social status.

Table 5: Assessment of NAPEP's activities toward poverty reduction in Nigeria

\begin{tabular}{|c|c|c|c|c|c|c|c|}
\hline \multirow{2}{*}{$\begin{array}{l}\text { Do you think NAPEPE'S } \\
\text { objective of halving the } \\
\text { proportion of poverty by } \\
\text { the year } 2015 \text { could be } \\
\text { achieved? }\end{array}$} & \multicolumn{6}{|c|}{ How could you assess the performance of NAPEP in alleviating poverty? } & \multirow[t]{2}{*}{ Total } \\
\hline & No Response & Good & $\begin{array}{l}\text { Very } \\
\text { Good }\end{array}$ & Excellent & Poor & $\begin{array}{l}\text { Very } \\
\text { Poor }\end{array}$ & \\
\hline Yes & 0 & 28 & 18 & 12 & 2 & 0 & 60 \\
\hline No & 1 & 65 & 42 & 15 & 13 & 4 & 140 \\
\hline Total & 1 & 93 & 60 & 27 & 15 & 4 & 200 \\
\hline
\end{tabular}

Table 5 above presents the beneficiaries' assessment of the programme as regards poverty reduction in Bauchi Local Government. Majority of the beneficiaries studied assessed the performance as good. On the other side, however, majority of the respondents are optimistic that the main objective of the programme of halving the proportion of core poverty in the country by the 2015 could not be achieved.

Table 6: SPSS Output on Impact on NAPEP

\begin{tabular}{|c|c|c|}
\hline Response & Frequency & Percentage \\
\hline Yes & 191 & 95.5 \\
\hline No & 9 & 4.5 \\
\hline Total & 200 & 100 \\
\hline
\end{tabular}

\begin{tabular}{|l|c|c|}
\hline Response & Frequency & Percentage \\
\hline Improve my income & 47 & 24.60 \\
\hline Create job opportunity for me & 65 & 34.03 \\
\hline Improve my social status & 16 & 8.38 \\
\hline Improve my education & 5 & 2.62 \\
\hline All of the above & 58 & 30.37 \\
\hline Total & 191 & 100 \\
\hline
\end{tabular}

Table 7: SPSS Output on Assessment of NAPEP

\begin{tabular}{|l|c|c|}
\hline Response & Frequency & Percentage \\
\hline No response & 1 & 0.5 \\
\hline Good & 93 & 46.5 \\
\hline Very good & 60 & 30 \\
\hline Excellent & 27 & 13.5 \\
\hline Poor & 15 & 7.5 \\
\hline Very poor & 4 & 2 \\
\hline total & 200 & 100 \\
\hline
\end{tabular}




\begin{tabular}{|l|r|r|rr|}
\hline & Observed N & Expected N & \multicolumn{3}{|c|}{ Residual } \\
\hline YES & 191 & 100.0 & & 91.0 \\
NO & 9 & 100.0 & & -91.0 \\
Total & 200 & & & \\
\hline
\end{tabular}

Has The Scheme You Benefited From Helped To Improve Your Soci-Economic Status IF YES, HOW?

\begin{tabular}{|l|r|r|r|}
\hline & Observed N & Expected N & \multicolumn{1}{|c|}{ Residual } \\
\hline IMPROVE MY INCOME & 47 & 38.2 & 8.8 \\
CREATE JOB OPPORTUNITY FOR ME & 65 & 38.2 & 26.8 \\
IMPROVE MY SOCIAL STATUS & 16 & 38.2 & -22.2 \\
IMPROVE MY EDUCATION & 5 & 38.2 & -33.2 \\
ALL OF THE ABOVE & 58 & 38.2 & 19.8 \\
Total & 191 & & \\
\hline
\end{tabular}

How Could You Assess The Methods Employed By NAPEP In Alleviating Poverty?

\begin{tabular}{|l|r|r|r|}
\hline & Observed N & Expected N & Residual \\
\hline NO RESPONSE & 1 & 33.3 & -32.3 \\
GOOD & 93 & 33.3 & 59.7 \\
VERY GOOD & 60 & 33.3 & 26.7 \\
EXCELLENT & 27 & 33.3 & -6.3 \\
POOR & 15 & 33.3 & -18.3 \\
VERY POOR & 4 & 33.3 & -29.3 \\
Total & 200 & & \\
\hline
\end{tabular}

\section{Test Statistics}

\begin{tabular}{|l|r|r|r|}
\hline & $\begin{array}{c}\text { HAS THE SCHEME YOU } \\
\text { BENEFITED FROM HELPED TO } \\
\text { IMPROVE YOUR SOCI- } \\
\text { ECONOMIC STATUS }\end{array}$ & IF YES, HOW? & $\begin{array}{c}\text { HOW COULD YOU ASSESS } \\
\text { THE METHODS EMPLOYED } \\
\text { BY NAPEP IN } \\
\text { ALLEVIATING POVERTY? }\end{array}$ \\
\hline Chi-Square & $165.620^{\mathrm{a}}$ & $72.848^{\mathrm{b}}$ & $196.600^{\mathrm{c}}$ \\
df & 1 & 4 & 5 \\
Asymp. Sig. & .000 & .000 & .000 \\
\hline
\end{tabular}

a. 0 cells $(.0 \%)$ have expected frequencies less than 5 . The minimum expected cell frequency is 100.0.

b. 0 cells $(.0 \%)$ have expected frequencies less than 5 . The minimum expected cell frequency is 38.2.

c. 0 cells $(.0 \%)$ have expected frequencies less than 5 . The minimum expected cell frequency is 33.3. 